Periodontoloji anabilim dalı öğrenci kliniğinde 2012-2014 yıllarında tedavi edilen hastaların periodontal ve sistemik durumları

\section{Periodontal and systemic health conditions of the patients treated in the student clinic of department of periodontology betweeen the years 2012-2014}

\author{
Dr. Sinem Demir Kodalak \\ Marmara Üniversitesi, Dişhekimliği Fakültesi, \\ Periodontoloji A.D., İstanbul
}

Yrd. Doç. Dr. Hafize Öztürk Özener Marmara Üniversitesi, Dişhekimliği Fakültesi, Periodontoloji A.D., istanbul

Yrd. Doç. Dr. Ömer Birkan Ağralı Marmara Üniversitesi, Dişhekimliği Fakültesi, Periodontoloji A.D., İstanbul

Yrd. Doç. Dr. Hatice Selin Yıldırım

Marmara Üniversitesi, Dişhekimliği Fakültesi, Periodontoloji A.D., İstanbul

Prof. Dr. Leyla Kuru

Marmara Üniversitesi, Dişhekimliği Fakültesi, Periodontoloji A.D., Istanbul

Geliş tarihi: 04 Mayıs 2017

Kabul tarihi: 03 Ağustos 2017

doi: 10.5505/yeditepe.2017. 25733

\section{Yazışma adresi:}

Yrd. Doç. Dr. Hafize Öztürk Özener

Marmara Üniversitesi Başıbüyük Sağlık Yerleşkesi, Dişhekimliği Fakültesi, Periodontoloji Anabilim Dalı, Başıbüyük, Maltepe, İstanbul

Tel: 05053765376

E-posta: hafize.ozturk@marmara.edu.tr
ÖZET

Amaç : Bu kesitsel retrospektif çalışmada, 2012 ila 2014 yılları arasında Marmara Üniversitesi Diş Hekimliği Fakültesi Periodontoloji Anabilim Dalı öğrenci kliniğinde başlangıç periodontal tedavileri yapılan hastaların periodontal ve sistemik durumları ile kişisel alışkanlıklarının değerlendirilmesi amaçlandı.

Gereç ve Yöntem: Çalışmaya dahil edilen 4050 bireyin hasta kartlarındaki demografik, sistemik ve dental anamnez bilgilerinden yararlanıldı; anamnez, kişisel alışkanlıklar (sigara kullanımı, diş fırçalama), hastaların radyografik ve klinik muayeneleri sonucunda teşhis edilen periodontal hastalık durumları belirlendi. Cinsiyetlerine (kadın, erkek) ve periodontal hastalık durumlarına (gingivitis, kronik periodontitis, agresif periodontitis) göre oluşturulan gruplar, sigara kullanımı, diş fırçalama alışkanlığı, plak indeks, gingival indeks, sondalama derinliği gibi periodontal klinik parametreler, diabetes mellitus, hipertansiyon, kalp ve damar hastalığı açısından karşılaştırıldı. Verilerin istatistiksel analizleri SPSS 15.0 paket programı kullanılarak yapıldı.

Bulgular: Yaş ortalaması $40.84 \pm 14.05$ populasyonun $\% 56.5^{\prime} i$ kadın ve \%44.5'i erkeklerden oluşuyordu. Diş fırçalama sıklığı kadın hastalarda daha fazla iken $(p<0.05)$, erkek hastalarda sigara kullanımı ve tüm periodontal klinik parametrelerin daha yüksek olduğu $(p<0.05)$ ancak periodontal hastalık, diabetes mellitus, hipertansiyon, kalp ve damar hastalıkları bakımından cinsiyetler arasında fark görülmediği $(p>0.05)$ tespit edildi. Periodontal hastalık gruplarında cinsiyet, yaş, sigara kullanımı, periodontal klinik parametreler, diabetes mellitus, hipertansiyon, kalp ve damar hastalıkları açısından istatistiksel olarak anlamlı fark tespit edildi $(p<0.001)$.

Sonuç: Toplam 4050 bireye ait klinik ve demografik verilerin analizi ile gerçekleştirilen bu çalışmada, sistemik hastalık ve durumlar ile kișisel alıșkanlıkların periodontal sağlığa olan etkisi ve özellikle diabetes mellitus, hipertansiyon, kalp ve damar hastalıkları ile periodontitisin ilişkisi ortaya konulmuştur. Anahtar kelimeler: Diabetes mellitus, hipertansiyon, periodontal hastalıklar, sigara içme.

\section{ABSTRACT}

Aim: In this retrospective cross-sectional epidemiologic study, it is aimed to assess systemic and periodontal health condition and individual habits of patients treated by undergraduate students in the clinic of Periodontology Department of the Faculty of Dentistry, Marmara University between years 2012-2014.

Materials and Methods: Systemic and dental records were collected from 4050 subjects along with their individual habits and diagnosis of periodontal disease. The patients were divided into groups according to gender (female, male) and periodontal disease condition (gingivitis, chronic periodontitis, aggressive periodontitis), and intergroup comprasions were carried out for smoking and tooth-brushing habits, peri- 
odontal clinical parameters (plaque index, gingival index and probing depth) and systemic diseases including diabetes mellitus, hypertension and cardiovascular disease. Statistical analyses were performed using SPSS 15.0 program.

Results: Mean age of the study population ( $56.5 \%$ female, $44.5 \%$ male) was $40.84 \pm 14.05$ years. While tooth-brushing habit was better in females $(p<0.05)$, smoking and periodontal clinical parameters were higher in males $(p<0.05)$. No significant differences were observed between females and males regarding periodontal disease, diabetes mellitus, hypertension, cardiovascular disease. There were statistically significant differences in gender, age, smoking, periodontal clinical parameters, diabetes mellitus, hypertension and cardiovascular disease among different periodontal disease groups $(p<0.001)$.

Conclusion: Analysis of records of 4050 individuals revealed that systemic diseases and conditions may effect periodontal health, and interactions between periodontitis and systemic diseases, particularly diabetes mellitus, hypertension, cardiovascular disease are evident.

Keywords: Diabetes mellitus, hypertension, periodontal diseases, smoking.

\section{GiRiş}

Periodontal hastalıklardan kronik gingivitis (KG), kronik periodontitis (KP) ve agresif periodontitis (AP) aynı primer etiyolojik faktöre sahip olan, ancak farklı klinik tablolar gösteren hastalıklardır. ${ }^{1-3}$ Enfeksiyona neden olan etkenin ortadan kaldırılmasıyla tam olarak iyileşebilen KG tablosunun yanında KP ve AP, dişleri destekleyen dokularda meydana gelen geri dönüşümsüz yıkımlarla kendini gösterir. KP genellikle 30-35 yaşlarında görülmeye başlar, lokal etiyolojik faktörlerin miktarı ile orantılı olarak meydana gelen ataşman kaybı ve kemik yıkımı yavaş ilerler ve devirseldir. Gelişiminde genetik yatkınlığın önemli rol oynadığı, erken yaşlarda ortaya çıkan AP'te, lokal etiyolojik faktörlerin miktarı, ataşman kaybı ve kemik yıkımı ile orantılı değildir; yıkım hızlı ve devirsel seyreder. AP, lokalize ve generalize olarak 2 alt gruba ayrılır. Lokalize AP, puberte döneminde 1. molar ve kesici dişlerde lokalize ataşman kaybı (en az iki kalıcı dişte) ile görülür. Enfeksiyöz ajanlara karşı güçlü antikor yanıtı mevcuttur. AP'nin generalize tipi, genellikle 30 yaşın altındaki bireylerde gözlenir fakat daha ileri yaşta da görülebilir. Generalize ataşman kaybı 1. molar ve kesiciler ile birlikte en az 3 kalıcı dişi daha içerir. Enfeksiyöz ajanlara karşı zayıf antikor yanıtı görülür. ${ }^{4}$

Periodontal hastalıkların birincil etkeni mikrobiyal dental plak (MDP) olmasına rağmen bazı sistemik ve metabolik faktörlerin hastalık şiddet ve prognozunu etkileyerek periodontal hastalık riskini arttırdığı konusunda günümüzde fikir birliği sağlanmıştır. Periodontal hastalık gibi lokalize veya fokal bir enfeksiyonun sistemik etkileri olabileceği düşüncesi 20. yüzyııın başlarında önem kazanmaya başlamıştır. ${ }^{5}$ Günümüzde ise lokal enfeksiyöz hastalıkların sistemik hastalıkların başlamasına neden olmasa da iki temel mekanizma ile seyrini etkilediği düşünülmektedir. Bu mekanizmalardan ilki bakteriyemi yoluyla uzak bölgelerde enfeksiyona neden olabilmesidir. ${ }^{6}$ Diğeri ise periodontal hastalık etkeni olan bakterilerin konakta oluşturdukları immün yanıtta karaciğer, pankreas, iskelet sistemi ve arterler gibi uzak bölgede bazı pro-enflamatuvar sitokinlerin veya akut faz proteinlerinin salınımını stimüle etmesi olabilir.6,7

Günümüzde periodontal hastalıkların diabetes mellitus, kardiyovasküler hastalıklar, ateroskleroz, miyokard enfarktüsü, inme, pnömoni ve gebelik döneminde oluşan istenmeyen durumlar ile ilişkili olabileceği ve bu hastalık/ durumların birçoğunun periodontal hastalığın önlenmesi ve/veya tedavisiyle kontrolünün ve hatta önlenmesinin mümkün olduğu ileri sürülmektedir. ${ }^{8}$

Bu bilgilerin ışığında, yapmış olduğumuz bu retrospektif çalışmada kliniğimize başvuran hastalarda, periodontal hastalıkların yaşa ve cinsiyete göre dağılımını, hastalarda sistemik hastalık görülme sıklığını, hastaların oral hijyen sağlama ve sigara kullanma alışkanlıklarını incelemeyi amaçladık.

\section{GEREÇ VE YÖNTEM}

\section{Çalışma dizaynı ve popülasyonu}

Bu kesitsel retrospektif çalışmaya Marmara Üniversitesi Diş Hekimliği Fakültesi Periodontoloji Anabilim Dalı'nda 2012-2014 yılları arasında klinik ve radyografik muayeneleri sonucunda periodontal hastalık teşhisi konmuş ve öğrenci kliniğinde bilgilendirilmiş onam formları okutulup imzalatılarak başlangıç periodontal tedavileri tamamlanmış olan hastaların arşivlenmiş hasta kartları dahil edildi. Hasta kartlarında yer alan demografik, sistemik ve dental anamnez bilgilerinden yararlanıldı. Çalışma protokolü Marmara Üniversitesi Sağlık Bilimleri Enstitüsü Etik Kurulu'nda 26.01.2015 tarih ve 158 sayı ile onaylandı.

\section{Klinik ölçümler}

Çalışma için gerekli bilgilerin eksiksiz olarak doldurulduğu hasta kartlarında, hastaların kişisel bilgileri (ad, soyad, yaş, cinsiyet), kişisel alışkanlık bilgileri (sigara kullanımı ve diş fırçalama sıklığı), sistemik anamnez bilgileri (diabetes mellitus, hipertansiyon ve kalp-damar hastalıkları) ile tedavi öncesi plak indeks (Pi), gingival indeks (Gi) ve sondalama derinliği (SD) ölçümleri mevcuttu. PI değerlerini belirlemek için Silness ve Löe $^{9}$ tarafından geliştirilen indeks kullanıldı. Dişler pamuk tamponlarla izole edilip hava ile kurutulduktan sonra, 4 yüzeydeki dişeti kenarına yakın bölgedeki MDP boyanmadan gözle ve muayene sondu ile incelendi. Gi değerleri, Löe ve 
Silness ${ }^{\prime}$ in $^{10}$ geliştirdiği indeks göz önüne alınarak, her dişin 4 bölgesindeki dişetinin renk, ödem, kıvam ve periodontal sondun dişeti oluğunun yumuşak doku duvarı boyunca gezdirilmesi sonucu oluşan kanama durumu değerlendirilerek belirlendi. SD, periodontal sond periodontal cebin tabanına kadar yerleştirilip cep tabanı ile serbest dişeti kenarı arasındaki mesafe ölçülerek saptandı. Meziyobukkal, midbukkal, distobukkal ve midlingual olmak üzere dişlerin 4 noktasından ölçüm yapıldı.

\section{Grupların oluşturulması}

Araştırmaya dahil edilen bireylerin yaş, cinsiyet, sigara kullanımı, diş fırçalama alışkanlıkları, periodontal hastalık ve sistemik hastalık durumuna göre dağılımları incelendi. Bireyler cinsiyet (kadın/erkek) ve periodontal hastalık (KG, KP, AP) durumuna göre gruplandırıldı. Periodontal hastalık grupları, 1999 yılında American Academy of Periodontology tarafından geliştirilen sınıflama göz önüne alınarak oluşturuldu. ${ }^{11}$

\section{İstatistiksel analiz}

Klinik verilerin sunulmasında ve değerlendirilmesinde tanımlayıcı istatistikler; niteliksel değişkenler için sayı ve yüzde, niceliksel değişkenler için ortalama, standart sapma, minimum ve maksimum olarak verildi. Verilerin istatistiksel analizleri SPSS 15.0 paket programı kullanılarak yapıldı. Niceliksel değişkenlerin dağıımının normal olup olmadığı Kolmogorov Smirmov testi ile değerlendirildi. Niteliksel verilerin gruplar arası karşılaştırması Pearson Ki-Kare testi ile normal dağılım göstermeyen niceliksel verilerin çoklu karşılaştırması Kruskal-Wallis testi, ikili karşılaştırması Mann-Whitney U testi ile yapıldı. Parametreler arasındaki korelasyonlarda Spearman Korelasyon testi kullanıldı. Periodontitis için yaş, sigara kullanımı, cinsiyet gibi değişkenlerin etkisini değerlendirebilmek, sistemik hastalıklar için ise periodontitisin etkisini değerlendirebilmek için lojistik regresyon analizi yapıldı. Sonuçlar \%95 güven aralığında ve istatistiksel anlamlılık $p<0.05$ düzeyinde değerlendirildi.

\section{BULGULAR}

Marmara Üniversitesi Diş Hekimliği Fakültesi Periodontoloji Anabilim Dalı Kliniği'ne 2012-2014 yılları arasında başvuran hastalardan öğrenci kliniğinde tedavi edilen toplam 4050 bireyin eksiksiz doldurulmuş hasta kartları değerlendirildi.

Bireylerin demografik, alışkanlık, periodontal klinik, periodontal hastalık ve sistemik hastalık verilerinin cinsiyete göre karşılaştırılması Tablo 1'de görülmektedir. Populasyonun \%56.5'ini oluşturan kadın bireylerin yaş ortalaması $40.37 \pm 13.76$ iken $\% 43.5^{\prime}$ ini oluşturan erkek bireylerinki $41.46 \pm 14.39$ olarak saptandı ve istatistiksel anlamlı fark gözlendi $(p<0.05)$. Erkek bireylerde kadın bireylere kıyasla, günlük kullanılan sigara adedi istatistiksel olarak yüksek tespit edilirken, diş fırçalama sıklığı yüzdesi düşük bulundu $(p<0.001)$.

Erkek hastalarda SD $(p<0.05)$, Gi $(p<0.001)$ ve Pi $(p=0.001)$ değerlerinin kadın hastalara kıyasla daha yüksek olduğu tespit edildi. Ancak cinsiyetler arasında periodontal hastalık bakımından fark görülmedi ( $p>0.05$ ) (Tablo 1).

Tablo 1. Çalışmaya dahil edilen bireylere ait demografik, alışkanlık, periodontal klinik, periodontal hastalık ve sistemik hastalık verilerinin cinsiyete göre karşılaştırılması.

\begin{tabular}{|c|c|c|c|c|c|}
\hline \multirow{2}{*}{\multicolumn{2}{|c|}{ Hasta popülasyonu }} & $\begin{array}{c}\text { Toplam } \\
\text { N (\%) }\end{array}$ & $\begin{array}{l}\text { Kadın } \\
\text { N (\%) }\end{array}$ & $\begin{array}{l}\text { Erkek } \\
\text { N (\%) }\end{array}$ & $P$ \\
\hline & & $4050(100)$ & $2288(56.5)$ & $1762(43.5)$ & \\
\hline Yaş & $\begin{array}{l}\text { Ort } \pm \text { Ss } \\
\text { Min-Max }\end{array}$ & $\begin{array}{c}40.84 \pm 14.05 \\
10-94\end{array}$ & $\begin{array}{c}40.37 \pm 13.76 \\
11-94\end{array}$ & $\begin{array}{c}41.46 \pm 14.39 \\
10-86\end{array}$ & $0.013 *$ \\
\hline Sigara kullanım & & $1258(31.1)$ & & & \\
\hline Adet/gün & & $4.15 \pm 7.87$ & $3.06 \pm 6.41$ & $5.56 \pm 9.25$ & $0.000^{\beta}$ \\
\hline Min-Max & & $0-60$ & $0-40$ & $0-60$ & \\
\hline Diş Furçalama & $\begin{array}{l}\text { Evet } \\
\text { Hayur }\end{array}$ & $\begin{array}{c}3895(96.2) \\
155(3.8)\end{array}$ & $\begin{array}{c}2231(97.5) \\
57(2.5)\end{array}$ & $\begin{array}{c}1664(94.4) \\
98(5.6)\end{array}$ & $0.000^{\beta}$ \\
\hline SD $(\mathbf{m m})($ Ort \pm & & $2.74 \pm 0.63$ & $2.72 \pm 0.61$ & $2.77 \pm 0.65$ & $0.048 *$ \\
\hline Gi (Ort \pm Ss) & & $1.62 \pm 0.23$ & $1.61 \pm 0.23$ & $1.64 \pm 0.24$ & $0.000^{*}$ \\
\hline PÍ (Ort \pm Ss) & & $1.86 \pm 0.24$ & $1.85 \pm 0.23$ & $1.88 \pm 0.24$ & $0.001^{*}$ \\
\hline Periodontitis & $\begin{array}{l}\text { Var } \\
\text { Yok }\end{array}$ & $\begin{array}{c}3064(75.7) \\
986(24.3)\end{array}$ & $\begin{array}{c}1710(74.7) \\
578(25.3)\end{array}$ & $\begin{array}{c}1354(76.8) \\
408(23.2)\end{array}$ & $\mathrm{AD}^{\beta}$ \\
\hline KG & & $986(24.3)$ & $578(58.6)$ & $408(41.4)$ & $\mathrm{AD}^{*}$ \\
\hline KP & & $3007(74.3)$ & $1687(56.1)$ & $1320(43.9)$ & $\mathrm{AD}^{*}$ \\
\hline $\mathbf{A P}$ & & $57(1.4)$ & $23(40.4)$ & $34(59.6)$ & $\mathrm{AD}^{*}$ \\
\hline $\begin{array}{l}\text { Sistemik } \\
\text { hastalık }\end{array}$ & $\begin{array}{l}\text { Var } \\
\text { Yok }\end{array}$ & $\begin{array}{l}1676(41.6) \\
2374(58.6)\end{array}$ & $\begin{array}{l}1035(45,2) \\
1253(54,8)\end{array}$ & $\begin{array}{c}641(36.4) \\
1121(63.6)\end{array}$ & $0.000^{\beta}$ \\
\hline $\begin{array}{l}\text { Diabetes } \\
\text { mellitus }\end{array}$ & $\begin{array}{l}\text { Var } \\
\text { Yok }\end{array}$ & $\begin{array}{c}312(7.7) \\
3738(92.7)\end{array}$ & $\begin{array}{c}171(7.5) \\
2217(92.5)\end{array}$ & $\begin{array}{c}141(8) \\
1621(92)\end{array}$ & $\mathrm{AD}^{\beta}$ \\
\hline Hipertansiyon & $\begin{array}{l}\text { Var } \\
\text { Yok }\end{array}$ & $\begin{array}{c}491(12.1) \\
3559(87.9)\end{array}$ & $\begin{array}{c}295(12.9) \\
1193(87.1)\end{array}$ & $\begin{array}{c}196(11.1) \\
1566(88.9)\end{array}$ & $\mathrm{AD}^{\beta}$ \\
\hline $\begin{array}{l}\text { Kalp ve Damar } \\
\text { Hastalıkları }\end{array}$ & $\begin{array}{l}\text { Var } \\
\text { Yok }\end{array}$ & $\begin{array}{c}179(4.4) \\
3871(95.6)\end{array}$ & $\begin{array}{c}101(4.4) \\
2187(95.6)\end{array}$ & $\begin{array}{c}78(4.4) \\
1684(95.6)\end{array}$ & $\mathrm{AD}^{\beta}$ \\
\hline
\end{tabular}

$\star$ Mann Whitney-U test, $\beta$ Pearson Chi-Square test, $p<0.05$, Ort \pm Ss: Aritmetik ortalama \pm Standart sapma, Anlamlı değil: AD.

Tablo 2. Demografik, kişisel alışkanlık, periodontal klinik ve sistemik hastalık verilerinin periodontal hastalık durumuna göre karşılaştırılması.

\begin{tabular}{|c|c|c|c|c|c|c|}
\hline & & $\begin{array}{l}\text { Total } \\
\text { N (\%) }\end{array}$ & $\begin{array}{c}\text { KG } \\
\text { N (\%) }\end{array}$ & $\begin{array}{c}\text { KP } \\
\text { N (\%) }\end{array}$ & $\begin{array}{c}\text { AP } \\
\text { N (\%) }\end{array}$ & $P$ \\
\hline Yaş (Ort \pm Ss) & & $40.84 \pm 14.05$ & $24.52 \pm 8.49$ & $46.27 \pm 11.13$ & $36.68 \pm 7.59$ & $0.000^{\mu}$ \\
\hline Sigara & Var & $1258(31.1)$ & $235(23.8)$ & $1423(47.3)$ & $18(31.6)$ & $0.000^{\beta}$ \\
\hline Kullanımı & Yok & $2792(68.9)$ & 751 (76.2) & $1584(52.7)$ & $39(68.4)$ & \\
\hline Diş Fırçalama & Evet & $3895(96.2)$ & $955(\% 96.9)$ & $2888(\% 96)$ & $52(91,2)$ & $\mathrm{AD}^{\beta}$ \\
\hline & Hayır & $155(3.8)$ & $31(\% 3.1)$ & $119(\% 4)$ & $5(8.8)$ & \\
\hline $\mathrm{SD}(\mathrm{mm})\left(\mathrm{Ort}^{\prime} \pm \mathrm{S}\right.$ & & $2.74 \pm 0.63$ & $2.27 \pm 0.40$ & $2.87 \pm 0.59$ & $4.03 \pm 0.67$ & $0.000^{\mu}$ \\
\hline Gi $($ Ort \pm Ss) & & $1.62 \pm 0.23$ & $1.57 \pm 0.21$ & $1.63 \pm 0.24$ & $1.87 \pm 0.26$ & $0.000^{\mu}$ \\
\hline Pİ (Ort \pm Ss) & & $1.86 \pm 0.24$ & $1.80 \pm 0.22$ & $1.88 \pm 0.24$ & $1.94 \pm 0.21$ & $0.000^{\mu}$ \\
\hline Sistemik & Var & $1676(41,4)$ & $235(23.8)$ & $1423(47.3)$ & $18(31.6)$ & $0.000^{\beta}$ \\
\hline hastalık & Yok & $2374(58,6)$ & $751(76.2)$ & $1584(52,7)$ & $39(68.4)$ & \\
\hline Diabetes & Var & $312(7.7)$ & $10(1)$ & $299(9.9)$ & $3(5.3)$ & $0.000^{\beta}$ \\
\hline mellitus & Yok & $3738(92.7)$ & $976(99)$ & $2708(90.1)$ & $54(94.7)$ & \\
\hline Hipertansiyon & Var & $491(12.1)$ & $6(0.6)$ & $481(16)$ & $4(7)$ & $0.000^{\beta}$ \\
\hline & Yok & $3559(87.9)$ & $980(99.4)$ & $2526(84)$ & $53(93)$ & \\
\hline Kalp ve Damar & Var & $179(4.4)$ & $10(1)$ & $169(5.6)$ & $0(0)$ & $0.000^{\beta}$ \\
\hline Hastalıkları & Yok & $3871(95.6)$ & $976(99)$ & $2838(94.4)$ & $57(100)$ & \\
\hline
\end{tabular}

${ }^{\mu}$ Kruskal- Wallis test, ${ }^{\beta}$ Pearson Chi-Square test, $\mathrm{p}<0.05, \mathrm{Ort} \pm \mathrm{Ss}$ : Aritmetik ortalama \pm Standart sapma, Anlamlı değil: $\mathrm{AD}$ 
Kadınların \%45.2'sinde $(n=1035)$ sistemik hastalık saptanırken, bu oran erkeklerde \%36.4 ( $\mathrm{n}=641)$ idi. Diabetes mellitus, hipertansiyon, kalp ve damar hastalıkları bakımından kadın ve erkek hastalar arasında farklılık saptanmadı $(p>0.05)$. Çalışmaya katılan bireyler periodontal hastalık teşhisine göre $\mathrm{KG}, \mathrm{KP}$ ve AP olarak gruplara ayrılarak incelendi. Bireylerin \%24.3'ü ( $n=986) K G$, \%74.3'ü $(n=3007)$ KP ve \%1.4'ü $(n=57)$ AP olarak tespit edildi (Tablo 1).

Tablo 1 ve 2'de görüldüğü gibi cinsiyet, yaş ve sigara kullanımı açısından bu üç grup arasında istatistiksel olarak anlamlı fark tespit edildi $(p<0.001)$. Tüm periodontal klinik parametrelerin yanında sistemik hastalık varlığı, diabetes mellitus, hipertansiyon, kalp ve damar hastalıkları açısından da KG, KP ve AP grupları arasında anlamlı fark görüldü $(p<0.001)$.

Populasyondaki tüm bireylerin yaşı ile sigara kullanımı $(p<0.05)$ ve sistemik hastalık varlığı arasında anlamlı pozitif ilişki $(p<0.01)$; periodontits ile yaş, sigara kullanımı ve sistemik hastalık arasında anlamlı pozitif ilişki tespit edildi $(p<0.01)$ (Tablo 3).

Tablo 3. Demografik veriler ile hastaların alışkanlık, periodontal ve sistemik hastalıklarının korelasyonu.

\begin{tabular}{|c|c|c|c|c}
\hline & $\begin{array}{c}\text { Sigara } \\
\text { Kullanımı }\end{array}$ & $\begin{array}{c}\text { Diş } \\
\text { Firçalama }\end{array}$ & Periodontitis & $\begin{array}{c}\text { Sistemik } \\
\text { Hastalık }\end{array}$ \\
\hline Yaş & $0.034^{*}$ & -0.011 & $0.650^{* *}$ & $0.331^{* *}$ \\
\hline Sigara Kullanımı & - & -0.022 & $0.126^{* *}$ & 0.04 \\
\hline Diş Firçalama & & - & -0.20 & 0.016 \\
\hline Periodontitis & & & - & $0.202^{* *}$ \\
\hline Sistemik Hastalık & & & & - \\
\hline
\end{tabular}

Ayrıca, yaş ile sigara kullanımı, Pi, Gi ve SD arasında anlamlı pozitif ilişki olduğu saptandı $(p<0.01)$ (Tablo 4).

Tablo 4. Periodontal klinik veriler ile kantitatif demografik veriler arasındaki ilişki.

\begin{tabular}{|c|c|c|c|c}
\hline & $\begin{array}{c}\text { Sigara } \\
\text { Kullanımı } \\
\text { (adet/gün) }\end{array}$ & Pi & Gi & SD \\
\hline Yaş & $0.042^{* *}$ & $0.133^{* *}$ & $0.098^{* *}$ & $0.386^{* *}$ \\
\hline $\begin{array}{c}\text { Sigara Kullanımı } \\
\text { (adet/gün) }\end{array}$ & - & $0.164^{* *}$ & $0.041^{* *}$ & $0.129^{* *}$ \\
\hline Pí & & - & & \\
\hline Gi & & $0.300^{* *}$ & - & \\
\hline SD & & $0.297^{* *}$ & $0.072^{* *}$ & \\
\hline
\end{tabular}

Spearman Korelasyon testi, $* * p<0.01$

Sigara kullanımı ile tüm periodontal klinik veriler arasında anlamlı pozitif ilişkinin $(p<0.01)$ yanında periodontal klinik verilerin birbirleriyle ilişkileri incelendiğinde SD ile Pi ve Gi arasında ve Pi ile Gi arasında anlamlı pozitif ilişki olduğu görüldü $(p<0.01)$ (Tablo 4). Tablo 5 'te görüldüğü gibi periodontitis varlığı ile diabetes mellitus, kalp ve damar hastalıkları ve hipertansiyon varlığı arasında anlamlı pozitif ilişki tespit edildi $(p<0.01)$. Bunun yanında, sigara kullanımının periodontitis olasılığını 2.07 kat; periodon- titisin de diabetes mellitus ve hipertansiyon olasılığını sırasıyla 4.49 ve 7.17 kat arttırdığı görüldü.

Tablo 5. Periodontitis ile sistemik hastalıklar arasındaki ilişki.

\begin{tabular}{|c|c|c|c}
\hline & Diabetes mellitus & Kalp ve Damar & Hipertansiyon \\
\hline Periodontitis & $0.142^{* *}$ & $0.094^{* *}$ & $0.200^{* *}$ \\
\hline Diabetes mellitus & - & $0.105^{* *}$ & $0.284^{* *}$ \\
\hline Kalp ve Damar & & - & $0.318^{* *}$ \\
\hline Hipertansiyon & & & - \\
\hline
\end{tabular}

Tablo 6. Periodontitisin yaș, sigara ve cinsiyet durumuna göre, diabetes mellitus, kalp ve damar ve hipertansiyonun periodontitis durumuna gore regresyonu.

\begin{tabular}{|l|c|c|c|c}
\hline \multicolumn{1}{c|}{$\begin{array}{c}\text { Bağımlı } \\
\text { Değișken }\end{array}$} & $\begin{array}{c}\text { Bağımsız } \\
\text { Değișken }\end{array}$ & $\mathbf{p}$ & OO & \% 95 GA \\
\hline Periodontitis & Cinsiyet & 0.325 & 0.325 & $0.902-1.366$ \\
\cline { 4 - 5 } & Sigara Kullanımı & $\mathbf{0 . 0 0 0}$ & 2.073 & $1.639-2.621$ \\
\hline Diabetes mellitus & \multirow{2}{*}{ Periodontitis } & 0.105 & 1.887 & $0.876-4.065$ \\
\cline { 1 - 1 } Kalp ve Damar & & $\mathbf{0 . 0 0 0}$ & 4.496 & $2.183-9.258$ \\
\cline { 1 - 1 } Hipertansiyon & & $\mathbf{0 . 0 0 0}$ & 7.175 & $3.101-16.600$ \\
\hline
\end{tabular}

Lojistik Regresyon Analizi, p< $0.05, \mathrm{OO}$ : odss oran1, \%95 güven aralı̆̆

\section{TARTIŞMA}

MDP primer etiyolojik faktör olmasına rağmen periodontal hastalıkların başlaması, ilerlemesi ve şiddetlenmesinde rol oynayan farklı risk faktörlerinin olduğunu gösteren geniş epidemiyolojik ve deneysel çalışmalar vardır. ${ }^{12-15}$ Bu çalışmalara göre; çevresel (cinsiyet, sigara, alkol), sistemik (diabetes mellitus, obezite, kardiyovasküler hastalıklar vb) ve genetik faktörler periodontal hastalıklar ile ilişkilidir. ${ }^{16,17}$ Çalışmamızın sonuçlarıyla benzer olarak kadınların daha sık diş fırçaladığını destekleyen 1999 yılında Japonya'da gerçekleştirilen çalışmada erkeklerin \% 60.9'nun, kadınların \% 88.8'nin yatmadan önce diş fırçaladıkları rapor edilmiştir. ${ }^{18}$ Çalışmamızda cinsiyetler arasında periodontal hastalık bakımından fark bulunmaması literatürle benzerlik göstermektedir. ${ }^{19}$

Periodontal hastalıkların ilerlemesi ve patogenezinde en önemli risk faktörü olan sigaranın, şiddetli kemik ve ataşman kaybıyla ilişkili olduğu gösterilmiştir. ${ }^{20-23}$ Nociti ve ark.'nın ${ }^{24}$ çalışmasında sigaranın periodontitis için başlıca çevresel risk faktörü olduğu bildirilmiştir. Son zamanlarda yapılan deneysel ve klinik çalışmalar, sigaranın periodontal hastalık üzerine olan immun enflamatuvar etkisine odaklanmıştır. Damarlarda vazokonstrüksiyon, kan akımında azalma, osteoklast aktivitesinde artış, kollajen sentezinde azalma ve kollajenaz üretiminde artışa neden olarak lokal ${ }^{25-27}$ yollarla, PMNL'lerin fagositoz ve kemotaksis fonksiyonlarında bozulma, proenflamatuvar sitokinlerin salınımında artış ve periodontopatojenlere karşı antikor üretimini azalmaya neden olarak sistemik ${ }^{27,28}$ yollarla periodontal hastalık patogenezinde ve gelişiminde rol oynamaktadır. Sigara içen bireylerin içmeyenlere göre periodontal hastalığa yakalanma olasılığının 3-6 kez daha fazla olduğu rapor edilmiștir. ${ }^{29}$ Sigara kullanımı ile periodontal hastalık arasındaki ilişki- 
nin doza bağlı olduğu, sigara kullanılan zaman ile içilen günlük sigara sayısı arttıkça periodontitis şiddetinin de arttığı bildirilmiştir. ${ }^{29,30}$ Çalışmamızda da literatürle paralel şekilde, sigara kullanan bireylerde klinik periodontal göstergelerin anlamlı olarak daha yüksek çıkmasının yanında sigara kullanımının periodontitis olasılığını 2 kat artırdığı tespit edildi.

Yaklaşık olarak son yirmi yıllık dönemde farklı kronik sistemik hastalıklar ve durumlar ile periodontal hastalık arasındaki potansiyel ilişkiye yönelik yoğun bir ilgi olmuştur. ${ }^{31}$ Periodontitisin diğer hastalıklar için bir risk faktörü olabileceği, hastalıkların gelişimini ve prognozunu etkileyebileceği ileri sürülmüştür. ${ }^{32,33}$

Diabetes mellitus ve periodontitis arasında karşılıklı çift yönlü etkileşim vardır. Bunun temelinde hastalıkların patolojisine dayalı olarak ortaya çıkan moleküler mekanizmaların rol oynadığı düşünülmektedir. ${ }^{34}$ Diabetes mellitus olan bireylerde periodontal hastalık prevelansının oldukça yüksek olduğu bildirilmiştir. ${ }^{34-37}$ Diabetes mellituslu hastalarda görülen proenflamatuvar sitokinlerde artış, PMNL disfonksiyonu, kolajende anormal çapraz bağlanma, glikozilasyon, büyüme faktörlerinde salınım bozuklukları ve yara iyileşmesinde meydana gelen gecikme bu kişilerin periodontitise yatkın olma sebepleri arasında gösterilmiștir. ${ }^{38-40}$ Khader ve ark.'nın ${ }^{41}$ yaptığı meta-analiz sonucunda diabetes mellituslu bireylerin daha zayıf oral hijyene sahip olduğu ve diabetes mellitus olmayan bireylere göre daha şiddetli periodontal hastalık görüldüğü belirtilmiştir. Literatürle benzer şekilde, çalışmamızda diabetes mellitus olan bireylerde olmayanlara göre periodontitis varlığı açısından önemli fark bulundu ve periodontitisin diabetes mellitus riskini yaklaşık 4,5 kat arttırdığı tespit edildi.

C-reactive protein (CRP) gibi kandaki enflamasyon markerlarının seviyesinin kardiyovasküler hastalık için bir risk göstergesi olduğu belirtilmiştir. ${ }^{42,43}$ Periodontal hastalıklarda enflamasyonla ilişkili olarak artış gösteren CRP, interlökin 6, interlökin 8, transforming growth factor-a gibi sistemik enflamasyon göstergelerinin aterogeneze ve periodontitisli hastalarda aterom plaklarının rüptürüne katkıda bulunduğu gösterilmiştir. ${ }^{44}$ Bununla birlikte periodontitis gibi kronik enflamatuvar hastalıkların kardiyovasküler hastalıklar için potansiyel sistemik enflamatuvar risk olduğu ve endotelyal disfonksiyona yol açtığı belirtilmiştir. ${ }^{44}$ Bu durumun damar duvarında kalınlaşmaya ve direnç artışına dolayısıyla yüksek kan basıncına neden olduğunu belirten çalışmalar mevcuttur. ${ }^{45,46}$ Periodontal hastalık ile kardiyovasküler hastalık arasındaki zayıf fakat istatistiksel olarak anlamlı ilișkiyi gösteren meta-analiz çalışmalarına dayanarak periodontitisli bireylerin kardiyovasküler hastalık gelişimi ya da ilerlemesinde daha büyük risk altında olduğu ve yine periodontitisin aterosklerotik damar hastalıkları için bilinen genel risk faktörlerinden (sigara içme, diabetes mellitus, obezite, genetik) bağımsız olarak tek başına önemli bir risk faktörü olduğu söylenebilir. ${ }^{47-49}$ Nikolaos ve ark. ${ }^{50}$ tarafından, 40-70 yaș aralığındaki 1552 kadın ve 1360 erkek üzerinde yapılan çalışmada periodontitis ile başlangıç kalp damar hastalığı arasındaki ilişki incelenmiștir. Kalp damar hastalıkları için marker olarak kullanılan total kolesterol, trigliserid, high-density lipoproteins (HDL) ve CRP seviyeleri ve klinik periodontal parametreleri kaydedilmiştir. Yapılan istatistiksel analizler sonucunda, periodontitis ile kalp damar hastalığına sahip olma, sigara içme, diş fırçalama sıklığı, kanda tespit edilen CRP, trigliserid, HDL kolestrol seviyeleri arasında önemli ilişkiler tespit edilmiştir. Çalışmamız55 bulgularında hipertansiyonlu, kardiyovasküler hastalığa sahip bireylerde ve bunlardan bağımsız olarak sigara kullanan bireylerde klinik periodontal göstergelerin anlamlı olarak daha yüksek çıktığını gördük. Çalışmamızda periodontitise sahip bireylerin kalp damar ve hipertansiyon hastası olma olasılığı anlamlı olarak daha yüksek olarak bulundu.

Bireylerin sistemik hastalık durum tespitlerinin hastaların kendi beyanları göz önüne alınarak yapılması, sistemik hastalık teşhisleri ile ilgili belirli bir standardizasyonun olmaması bu çalışmanın eksik yönlerinden sayılabilir. Yine her bir hastanın klinik periodontal ölçümleri sırasında aynı periodontal sond kullanılmış olsa da ölçümler farklı stajyer doktorlar tarafından yapılmıştır.

Yapılan bu kesitsel çalışma sonucunda, 40-50 bireye ait klinik ve demografik verilerin analizi gerçekleştirilmiş, sistemik hastalık ve durumlar ile kişisel alışkanlıkların periodontal sağlığa olan etkisi ve özellikle diabetes mellitus, hipertansiyon, kalp ve damar hastalıkları ve sigara kullanımı ile periodontitisin ilişkisi literatürde yapılan çalışma sonuçlarını destekler nitelikte ortaya koyulmuştur.

\section{SONUÇ}

Sonuç olarak diabetes mellitus, hipertansiyon, kalp ve damar hastalıkları bulunan bireylerde görülen yüksek periodontitis prevalansı, hem periodontitis hem de sistemik hastalıkların önlenmesi ve belki de tedavilerinin geliştirilmesi açılarından önem taşımaktadır. Klinisyenlerin özellikle sistemik hastalıklı bireylerde oral hijyen alışkanlıklarının gelişimi açısından çaba göstermesi ve hastaları periodontal hastalıklar ve sistemik hastalıklar ilişkisi yönünden bilgilendirmesi gereği de açıktır.

\section{KAYNAKLAR}

1. Ryan ME. Nonsurgical approaches for the treatment of periodontal diseases. Dent Clin North Am 2005; 49: 611 . 636.

2. Offenbacher S. Periodontal diseases: pathogenesis. Ann Periodontol 1996; 1: 821-878.

3. Barrington EP, Nevins M. Diagnosing periodontal dis- 
eases. J Am Dent Assoc 1990; 121: 460-464.

4. Parameter on aggressive periodontitis. American Academy of Periodontology. J Periodontol 2000; 71: 867-869.

5. Newman HN. Focal infection. J Dent Res 1996; 75: 1912-1919.

6. Pallasch TJ, Wahl MJ. The focal infection theory: appraisal and reappraisal. J Calif Dent Assoc 2000; 28: 194200.

7. Scannapieco FA. Systemic effects of periodontal diseases. Dent Clin North Am 2005; 49: 533-550.

8. Scannapieco FA, Dasanayake AP, Chhun N. "Does periodontal therapy reduce the risk for systemic diseases?". Dent Clin North Am 2010; 54: 163-181.

9. Silness J, Loe H. Periodontal Disease in Pregnancy.

li. Correlation between Oral Hygiene and Periodontal Condtion. Acta Odontol Scand 1964; 22: 121-135.

10. Loe H, Silness J. Periodontal Disease in Pregnancy. I. Prevalence and Severity. Acta Odontol Scand 1963; 21: 533-551.

11. The pathogenesis of periodontal diseases. J Periodontol 1999; 70: 457-470.

12. Haffajee AD, Socransky SS. Relationship of cigarette smoking to attachment level profiles. J Clin Periodontol 2001; 28: 283-295.

13. Dandona $P$, Aljada A, Bandyopadhyay A. Inflammation: the link between insulin resistance, obesity and diabetes. Trends Immunol 2004; 25: 4-7.

14. Bandyopadhyay D, Marlow NM, Fernandes JK, Leite RS. Periodontal disease progression and glycaemic control among Gullah African Americans with type-2 diabetes. J Clin Periodontol 2010; 37: 501-509.

15. Awuti G, Younusi K, Li L, Upur H, Ren J. Epidemiological survey on the prevalence of periodontitis and diabetes mellitus in Uyghur adults from rural Hotan area in Xinjiang. Exp Diabetes Res 2012; 2012:758921.

16. Salvi GE, Lang NP. Host response modulation in the management of periodontal diseases. J Clin Periodontol 2005; 32: 108-129.

17. Genco RJ, Borgnakke WS. Risk factors for periodontal disease. Periodontol 2000 2013; 62: 59-94.

18. Fukai K, Takaesu Y, Maki Y. Gender differences in oral health behavior and general health habits in an adult population. Bull Tokyo Dent Coll 1999; 40: 187-193.

19. Kissa J, et al. Aggressive and chronic periodontitis in a population of Moroccan school students. J Clin Periodontol 2016; 43: 934-939.

20. Bergstrom J. Cigarette smoking as risk factor in chronic periodontal disease. Community Dent Oral Epidemiol 1989; 17: 245-247.

21. Bergstrom J. Influence of tobacco smoking on periodontal bone height. Long-term observations and a hypothesis. J Clin Periodontol 2004; 31: 260-266.

22. Bergstrom J. Tobacco smoking and risk for periodon- tal disease. J Clin Periodontol 2003; 30: 107-113.

23. Grossi SG, et al. Assessment of risk for periodontal disease. I. Risk indicators for attachment loss. J Periodontol 1994; 65: 260-267.

24. Nociti FH, Jr., Casati MZ, Duarte PM. Current perspective of the impact of smoking on the progression and treatment of periodontitis. Periodontol 2000 2015; 67: 187-210.

25. Barbour SE, et al. Tobacco and smoking: environmental factors that modify the host response (immune system) and have an impact on periodontal health. Crit Rev Oral Biol Med 1997; 8: 437-460.

26. Fredriksson MI, Figueredo CM, Gustafsson A, Bergstrom KG, Asman BE. Effect of periodontitis and smoking on blood leukocytes and acute-phase proteins. J Periodontol 1999; 70: 1355-1360.

27. Guntsch A, et al. Effect of smoking on crevicular polymorphonuclear neutrophil function in periodontally healthy subjects. J Periodontal Res 2006; 41: 184-188.

28. Tangada SD, et al. The effect of smoking on serum IgG2 reactive with Actinobacillus actinomycetemcomitans in early-onset periodontitis patients. J Periodontol 1997; 68: 842-850.

29. Tomar SL, Asma S. Smoking-attributable periodontitis in the United States: findings from NHANES III. National Health and Nutrition Examination Survey. J Periodontol 2000; 71: 743-751.

30. Bergstrom J, Eliasson S, Dock J. A 10-year prospective study of tobacco smoking and periodontal health. $J$ Periodontol 2000; 71: 1338-1347.

31. Fowler EB, Breault LG, Cuenin MF. Periodontal disease and its association with systemic disease. Mil Med 2001; 166: 85-89.

32. De Stefano F, Anda RF, Kahn HS, Williamson DF, Russell CM. Dental disease and risk of coronary heart disease and mortality. BMJ 1993; 306: 688-691.

33. Linden GJ, et al. All-cause mortality and periodontitis in 60-70-year-old men: a prospective cohort study. J Clin Periodontol 2012; 39: 940-946.

34. Lacopino AM. Periodontitis and diabetes interrelationships: role of inflammation. Ann Periodontol 2001; 6: 125-137.

35. Goteiner D, Vogel R, Deasy M, Goteiner C. Periodontal and caries experience in children with insulin-dependent diabetes mellitus. J Am Dent Assoc 1986; 113: 277-279.

36. Oliver RC, Tervonen T. Diabetes--a risk factor for periodontitis in adults? J Periodontol 1994; 65: 530-538.

37. Selwitz RH, Nowjack-Raymer RE, Kingman A, Driscoll WS. Dental caries and dental fluorosis among schoolchildren who were lifelong residents of communities having either low or optimal levels of fluoride in drinking water. $J$ Public Health Dent 1998; 58: 28-35.

38. Nathan DM. The pathophysiology of diabetic 
complications: how much does the glucose hypothesis explain? Ann Intern Med 1996; 124: 86-89.

39. Mandrup-Poulsen T. Diabetes. BMJ 1998; 316: 1221 1225.

40. Schmidt AM, et al. Advanced glycation endproducts (AGEs) induce oxidant stress in the gingiva: a potential mechanism underlying accelerated periodontal disease associated with diabetes. J Periodontal Res 1996; 31: 508-515.

41. Khader YS, Dauod AS, El-Qaderi SS, Alkafajei A, Batayha WQ. Periodontal status of diabetics compared with nondiabetics: a meta-analysis. J Diabetes Complications 2006; 20: 59-68.

42. Hingorani AD, Shah T, Casas JP, Humphries SE, Talmud PJ. C-reactive protein and coronary heart disease: predictive test or therapeutic target? Clin Chem 2009; 55: 239-255.

43. Dauphinot V, et al. C-reactive protein implications in new-onset hypertension in a healthy population initially aged 65 years: the Proof study. J Hypertens 2009; 27: 736-743.

44. Beck JD, Slade G, Offenbacher S. Oral disease, cardiovascular disease and systemic inflammation. Periodontol 2000 2000; 23: 110-120.

45. Angeli $\mathrm{F}$, et al. Association between periodontal disease and left ventricle mass in essential hypertension. Hypertension 2003; 41(3): 488-492.

46. Inoue $K$, Kobayashi $Y$, Hanamura $H$, Toyokawa S. Association of periodontitis with increased white blood cell count and blood pressure. Blood Press 2005; 14: 53-58.

47. Janket SJ, Baird AE, Chuang SK, Jones JA. Meta-analysis of periodontal disease and risk of coronary heart disease and stroke. Oral Surg Oral Med Oral Pathol Oral Radiol Endod 2003; 95: 559-569.

48. Humphrey LL, Fu R, Buckley DI, Freeman M, Helfand $M$. Periodontal disease and coronary heart disease incidence: a systematic review and meta-analysis. J Gen Intern Med 2008; 23: 2079-2086.

49. Blaizot A, Vergnes JN, Nuwwareh S, Amar J, Sixou M. Periodontal diseases and cardiovascular events: meta-analysis of observational studies. Int Dent J 2009; 59: 197-209.

50. Chrysanthakopoulos NA, Chrysanthakopoulos PA. Clinically Classified Periodontitis and Its Association in Patients with Preexisting Coronary Heart Disease. J Oral Diseases 2013; 2013: 1-9. 
